\title{
Inability of normal human intestinal macrophages to form multinucleated giant cells in response to cytokines
}

\author{
S Fais, F Pallone
}

\begin{abstract}
Multinucleated giant cells are an important feature of the granulomatous reaction in Crohn's disease (CD) but their cellular origin is poorly understood. The aim of this study was to discover if intestinal macrophages are capable of generating multinucleated giant cells in vitro in response to cytokine stimulation. Human intestinal macrophages were isolated from the intestinal mucosa of CD and uninflamed surgical specimens. Isolated macrophages were cultured in chamber slides with and without exposure to a panel of cytokines and cell activators. Cell fusion, multinucleated giant cells formation, and the expression of adhesion molecules were assessed at various time intervals. In contrast with the autologous peripheral monocytes cell fusion was very poor in cultures of control intestinal macrophages and virtually no multinucleated giant cells were seen. Control intestinal macrophages seemed to poorly express the adhesion molecules required for cell to cell adhesion and fusion, namely ICAM-1 and LFA-1. None of these functions was affected by the exposure to cytokines, including interferon $\gamma$. In cultures of macrophages isolated from CD tissues multinucleated giant cell formation spontaneously occurred as early as three days and was not enhanced by the addition of cytokines. CD macrophages seemed to highly express both ICAM-1 and LFA-1. These data show that human intestinal macrophages are unable to form multinucleated giant cells in response to stimuli and support the concept that they are downregulated in a number of functions. The data also suggest that macrophages participating in the ganulomatous reaction in CD are recruited from the circulation.
\end{abstract}

(Gut 1995; 37: 798-801)

Keywords: intestine, Crohn's disease, macrophages, cytokines, multinucleated giant cells, ICAM-1.

Sperimentale, Università di $\mathbf{R}$ Calabria, Catanzaro, Italy

F Pallone

Correspondence to: Professor F Pallone Dipartimento di Medicina Sperimentale, Policlinico Universitario, Via T Campanella, 88100 Catanzaro, Italy.

Accepted for rapid publication

7 September 1995
Multinucleated giant cells are a prominen feature of the granulomatous reactior Crohn's disease (CD). ${ }^{12}$ The mechanisms and cellular requirements of multinucleated giant cell generation in CD tissues are not known. Recent evidence shows that 'in vitro' generation of multinucleated giant cells occur as a result of fusion of mature monocytes, ${ }^{34}$ and that the addition of various cytokines, ${ }^{4-9}$ specific antibodies, ${ }^{10}$ and mitogen ${ }^{11}$ modulate the ability of monocytes to fuse and form multinucleated giant cells. All human studies have been performed using peripheral monocytes, while the capability of human intestinal macrophages to form multinucleated giant cells is poorly understood. Interferon $\gamma$ (IFN $\gamma$ ) has been shown to be more potent than other cytokines in inducing the fusion of peripheral blood monocytes and the subsequent multinucleated giant cell generation by promoting sequential changes in cell morphology and in the cellular expression of adhesion molecules. ${ }^{4-6}$ Time course experiments with IFN $\gamma$ have shown that monocyte clustering and cell to cell adhesion are important sequential steps and that the polarisation of ICAM-1 on a cell uropode is essential for monocyte adhesion and fusion. ${ }^{4}$ As IFN $\gamma$ expression and release are increased in the inflamed gut tissues in CD, it seems conceivable that IFN $\gamma$ plays a part in the generation of multinucleated giant cells in CD. ${ }^{12-14}$ The aim of this study was to evaluate the ability of macrophages isolated from the intestinal mucosa of uninflamed and CD tissues to undergo cell fusion and form multinucleated giant cells in response to IFN $\gamma$ and other cytokines.

\section{Methods}

\section{Cell isolation and culture}

The source of intestinal lamina propria mononuclear cells were the affected areas of 10 resected specimens of CD patients (six distal ileum and four colon) and the unaffected areas of surgical specimens of 16 colonic cancer and four diverticular disease patients. Lamina propria mononuclear cells were isolated using the DTT-EDTA-collagenase sequence as previously described. ${ }^{15}$ Both lamina propria mononuclear cells and autologous peripheral blood mononuclear cells were resuspended in RPMI 1640 medium (Flow Lab, UK) supplemented with $10 \%$ heat inactivated immunoglobulin deprived human pooled serum, L-glutamine, and antibiotics. Cells were then placed in tissue culture chamber slides (Lab-Tek, USA) $\left(1.0 \times 10^{6}\right.$ cells/chamber), coated with $0.2 \mathrm{ml}$ prewarmed human pooled serum. Chambers were incubated for 90 minutes at $37^{\circ} \mathrm{C}$ in $5 \%$ $\mathrm{CO}_{2}$ humid atmosphere and non-adherent cells washed off with warm RPMI 1640. The resulting adherent cells consisted of $>90 \%$ macrophages and $<3 \% \mathrm{~T}$ cells by Giemsa stain and by immunocytochemistry with anti-CD3 
Cytokine driven clustering, cell fusion, and multinucleated giant cell generation in 10 day cultures of intestinal and peripheral slide adherent monocytes/macrophages. Clustering is expressed as the number of clusters per unit area (see methods), cell fusion as fusion index (\%) (see methods) and multinucleated giant cells as the number of multinucleated giant cells per unit area (see methods). Data are mean (SEM)

\begin{tabular}{|c|c|c|c|c|c|c|}
\hline & \multicolumn{2}{|l|}{ Clusters } & \multicolumn{2}{|l|}{ Fusion } & \multicolumn{2}{|c|}{ Multinucleated giant cell } \\
\hline & Intestinal & Peripheral & Intestinal & Peripheral & Intestinal & Peripheral \\
\hline IFN $\gamma$ & 0 & $28(3)$ & 0 & $78(4)$ & 0 & $14(4)$ \\
\hline IFN $\gamma$ & 0 & 0 & 0 & 0 & 0 & 0 \\
\hline ILl $\alpha$ & 0 & $23(10)$ & 0 & $4(2)$ & 0 & $6(2)$ \\
\hline IL1 $\beta$ & 0 & 0 & 0 & 0 & 0 & 0 \\
\hline IL4 & 0 & $1(1)$ & 0 & $2(1)$ & 0 & $1(1)$ \\
\hline IL6 & 0 & $24(9)$ & 0 & $40(5$ & 0 & $12(3)$ \\
\hline PMA & 0 & $10(2)$ & 0 & $8(3)$ & 0 & $5(2)$ \\
\hline
\end{tabular}

PMA $=$ phorbol-myristate-acetate

and anti-CD68 MoAb. Average cell yield was $1.6 \times 10^{5} /$ chamber in both peripheral and intestinal cultures.

\section{Multinucleated giant cells formation}

Slide adherent macrophages were cultured in the presence of various concentrations of the following: human recombinant IFNy (Boehringer Biochemia, Germany) (3, 10, 30, $100,300,1000 \mathrm{IU} / \mathrm{ml}$ ); IFN $\gamma$ (Bender MedSystem, Austria) (5, $10 \mathrm{IU} / \mathrm{ml}) ; \operatorname{ILl} \alpha$ (50, $200 \mathrm{pg} / \mathrm{ml}), \operatorname{IL} 1 \beta(5,20 \mathrm{pg} / \mathrm{ml}), \operatorname{IL} 4(10,100$ $\mathrm{ng} / \mathrm{ml}$ ); and IL6 (2, $30 \mathrm{ng} / \mathrm{ml}$ ) (Genzyme, USA). Phorbol-myristate-acetate $(1 \mu \mathrm{g} / \mathrm{ml})$ stimulation was also provided to compare mitogenic with cytokine stimulation. Aliquots of cells were preincubated with purified antiIFN $\gamma$ monoclonal antibody (Hoffman-La Roche, Switzerland) at fourfold excess ${ }^{13}$ or with anti-IL1, IL4, IL6 MAbs (Genzyme Co, USA) as appropriate. Cells were checked daily for clustering and fusion using an inverted microscope (Leitz Willovert). At 3, 5, 7, and 10 days of culture, the medium was removed from the slide chambers and adherent cells were fixed and stained with Giemsa. Macrophage fusion rate was determined by counting the number of nuclei within multinucleated giant cells ( $>3$ nuclei/cell) in a given area and the total number of nuclei in the same area. ${ }^{4}$ The fusion index was calculated according to the following formula: fusion index $(\%)=$ (number of nuclei within multinucleated giant cells)/(total number of nuclei counted) $\times$ 100. Using a $25 \times$ objective and a $10 \times$ eyepiece (Leitz Orthoplan Microscope) 500-800 nuclei from selected representative fields were counted for each experiment. The number of clusters were counted in each chamber area, using a grid mounted in the $10 \times$ eyepiece with a low magnification $(10 \times)$ objective thus permitting the observation of whole chamber slide. Counts were performed moving from the left upper square of the grid down to the lower one enumerating only clusters within squares. The final number was the sum of the clusters in each square.

Immunocytochemistry Immunophenotyping of fixed adherent macrophages was performed using the APAAP method. ${ }^{46}$ The following MAbs were used as first layer antibody: anti- CD54 (ICAM-1,
Immunotech International France, clone 84H10); anti-CD1 la (LFA1, Dako Denmark, clone MHM24); anti-CD68 (monocytes/ macrophages, Dako Denmark, clone EBM11). A rabbit-antimouse MAb (Dako, Denmark) was used as a second layer followed by the APAAP complex (Dako, Denmark). New Fuxin (Merk, Darmstadt, Germany) was used as chromogen. Negative controls were cells treated with the second layer antibody only, with the APAAP complex alone, and with irrelevant isotype matched antibodies. Mayer's haematoxylin was used as counterstain.

\section{Results}

\section{Cytokine driven multinucleated giant cell generation}

Intestinal macrophages did not seem to cluster after exposure to any of the cytokines tested, nor with phorbol-myristate-acetate (Table). There was virtually no fusion in the slide chamber adherent intestinal macrophages and no multinucleated giant cells were seen (Table). In contrast, both IFN $\gamma$ and IL6 seemed to dramatically enhance the generation of multinucleated giant cells in culture of the autologous peripheral monocytes (Table). The effect of IFN $\gamma$ and IL6 as assessed by fusion index, number of clusters and multinucleated giant cells, was dose and time dependent. With both cytokines, clustering of macrophages, cell adhesion and fusion were important sequential steps. Anti-IFNy Mab abrogated the effects of both IFN $\gamma$ and IL6. The fusion index in the anti-IFN $\gamma$ treated cultures did not differ to that of the unstimulated cultures (fusion index $0-2 \%$ ) at any time and with any IFN $\gamma$ and IL6 concentrations. Anti-IL6 Mab affected only IL6 driven multinucleated giant cell generation (not shown). In contrast, $C D$ intestinal macrophages spontaneously formed multinucleated giant cells as early as three days after cultures with no cytokine addition. The fusion index ranged between $22 \%$ and $35 \%$ and the number of multinucleated giant cells from 11 to 28 per chamber at three days.

ICAM-1 and LFA-1 on adherent macrophages, fused macrophages, and multinucleated giant cells Cells were examined by indirect immunocytochemistry after five days of culture with and without the addition of cytokines. Virtually all adherence purified macrophages were CD68 positive. ICAM-1 and LFA-1 were poorly expressed mean (SEM) 8 (3) \% and 5(3) \%, positive cells, respectively) by the CD68+ intestinal macrophages. The expression and cellular distribution of both ICAM-1 and LFA-1 on intestinal macrophages was not affected by the exposure to any of the cytokines tested in this study. After exposure to IFN $\gamma$ the percentages of positive macrophages were 6 (1) $\%$ for ICAM-1 and 5 (4) \% for LFA-1. In contrast, most peripheral monocytes strongly expressed both ICAM-1 (60 (4) \%) and LFA1 (81 (5) \%). As previously described, ${ }^{4}$ in response to IFN $\gamma$ and IL6, ICAM-1 was 
upregulated and polarised on the cell membrane region where cell to cell contact eventually occurred. When these cytokines were added seven days after culture no ICAM-1 enhancing effect was seen. Immunohistochemistry of CD tissue sections showed that the proportion of intestinal macrophages expressing both ICAM-1 and LF6-1 was much higher 89 (6) \% and 92 (7) \%, respectively), and that ICAM-1 tended to be polarised on cell uropode.

\section{Discussion}

Results of this study show that normal human intestinal macrophages are not able to form multinucleated giant cells in response to various cytokines. Consistent with this finding intestinal macrophages poorly expressed ICAM-1 and its counter-receptor LFA-1 whose expression was not affected by the exposure to any of the cytokines tested. As the enhancement of ICAM-1 and LFA-1 and the subsequent polarisation of ICAM-1 are required for multinucleated giant cell generation 'in vitro', it is conceivable that the inability of intestinal macrophages to form multinucleated giant cells in vitro is related to the lack of adhesion molecules enhancement. This would be in agreement with various findings showing that intestinal macrophages are downregulated in their capability of exerting a number of functions. In fact, normal intestinal macrophages are not able to express IL2R, ${ }^{17}$ to develop respiratory burst activity, ${ }^{18}$ to produce $\mathrm{ILl},{ }^{19}$ to release IFN $\gamma,{ }^{20}$ and express IFN $\gamma$ mRNA. ${ }^{12}$ Of interest, these functions are spontaneously activated in macrophages isolated from CD tissues. $^{12} 17-20$ We have shown here that CD intestinal macrophages spontaneously form multinucleated giant cells and that in $C D$ tissues the expression of both ICAM-1 and LFA- 1 is enhanced.

In $C D$ intestinal mucosa a spontaneous secretion of IFN $\gamma$ and increased IFN $\gamma$ mRNA has been shown ${ }^{12-14}$ and other putative in vitro' effects of IFN $\gamma$ have been shown, such as HLA-DR expression on intestinal epithelium, ${ }^{21-23}$ further suggesting that the inability of intestinal macrophages to 'in vitro' form multinucleated giant cells may well reflect an intrinsic cellular defect. The relevance of this finding to the granulomatous inflammatory reaction in Crohn's disease needs further investigation, as the responsiveness of macrophage/monocyte cells to IFN $\gamma$ is important in host resistance to infection, as shown by recent experiment with Leishmania in murine system. ${ }^{24}$

In conclusion, data of this study further support the view that normal human intestinal macrophages are cells downregulated in their capability to undergo fusion and multinucleated giant cell generation in response to IFN $\gamma$. This hypofunctional/hyporesponsive condition does not seem to be reversible, suggesting that tissue specific soluble factors may not be involved. Taken together, our data add indirect support to the concept that all the monocytes activated functions shown in CD tissues, including multinucleated giant cells generated, may result from peripheral monocyte recruitment and activation into the site of inflammation. ${ }^{25-26}$

These data were presented in part at the American Gastroenterological Association Meeting and published as an abstract in Gastroenterology 1993; 104: A698.

1 Adams DO. The granulomatous inflammatory response. A review. AM f Pathol 1976; 84: 164-91

2 Jayanthi V, Probert CS, Mackay EH, Williams GT, Mayberry JF. Granulomas in inflammatory bowel disease: are they of diagnostic or aetiological significance? Eur $\mathcal{F}$ Gastroenterol Hepatol 1992; 4: 15-7.

3 Murch AR, Grounds MD, Marshall CA, Papadimitriou JM Direct evidence that inflammatory multinucleated cells Direct evidence that inflammatory multin
form by fusion. $f$ Pathol $1981 ; 137: 17-23$.

4 Fais S, Burgio VL, Silvestri M, Capobianchi MR, Pacchiarotti A, Pallone F. Multinucleated giant cells generation induced by interferon gamma. Changes in the expression and distribution of the intercellular adhesion molecule-1. Lab Invest 1994; 71: 737-44.

5 Weimberg JB, Hobbs MM, Misukonis MA. Recombin ant human gamma-interferon induces human monocyte polykarion formation. Proc Natl Acad Sci USA 1984; 81: 4554-7.

6 Most J, Neumayer HP, Dierich MP. Cytokine-induced generation of multinucleated giant cells in vitro requires interferon-gamma and expression of LFA1. Eur f Immunol interferon-gamma

7 Chensue SW, Terebuh PD, Warmington KS, Hershey SD Evanoff HL, Kunkel SL, et al. Role of IL-4 and IFNgamma in Schistosoma mansoni EGG-induced hypersensitivity granuloma formation. Orchestration, relative contribution and relationship to macrophage function. f Immunol 1992; 148: 900-6.

8 Kurihara N, Bertolini D, Suda T, Akiyama Y, Roodman DG. IL-6 stimulates osteoclast-like multinucleated cell formation in long term human marrow cultures by inducing IL-1 release. $\mathcal{f}$ Immunol 1990; 144: $4226-30$.

9 McInnes A, Rennick DM. Interleukin 4 induces cultured monocytes/macrophages to form giant multinucleated cells. F Exp Med 1988; 167: 598-611.

10 Orentas RJ, Reinlib L, Hildreth JEK. Anti-class II MHC antibody induces multinucleated giant cell formation from peripheral blood monocytes. $\mathcal{F}$ Leukoc Biol 1992; 51: 199-209.

11 Hassan NF, Kamani N, Meszaros MM, Douglas SD Induction of multinucleated giant cell formation from human blood-derived monocytes by phorbol myristate acetate in vitro culture. F Immunol 1989; 143: 2179-84.

12 Fais S, Capobianchi $\mathrm{Mr}$, Silvestri M, Mercuri F, Dainzani $F$, Pallone F. Interferon expression in Crohn's disease patients: increased interferon-gamma and -alpha mRNA patients: increased interferon-gamma and -alpha mRNA in the intestinal lamina propr

13 Fais S, Capobianchi MR, Pallone F, Di Marco P, Boirivant $M$, Dianzani F, et al. Spontaneous release of interferongamma by intestinal lamina propria lymphocytes in Crohn's disease. Kinetics of in vitro response to interferon-gamma inducers. Gut 1991; 32: 403-7.

14 Breese EJ, Braegger CP, Corrigan CJ, Walker-Smith JA, MacDonald TT. Interleukin-2 and interferon-gamma secreting $T$ cells in normal and diseased human intestinal mucosa. Immunology 1993; 78: 127-31.

15 Pallone F, Fais S, Squarcia O, Biancone L, Pozzilli P, Boirivant $M$. Activation of peripheral and intestinal Boirivant $M$. Activation of peripheral and intestinal
lymphocytes in Crohn's disease. In vivo state of activation lymphocytes in Crohn's disease. In vivo state of activation
and in vitro response to stimulation as defined by the and in vitro response to stimulation as defined by the expression

16 Cordell JL, Falini B, Erber WN, Ghosh AK, Abdulaziz Z, MacDonald $S$, et al. Immunoenzymatic labelling of monoclonal antibodies using immunecomplexes of alkaline phosphatase and monoclonal anti-alkaline phosphatase (APAAP complex). $\mathcal{f}$ Histochem Cytochem 1984; 32: 219-29.

17 Mahida YR, Wu K, Patel S, Jewell DP. Interleukin-2 receptor expression by macrophages in inflammatory bowel disease. Clin Exp Immunol 1988; 74: 382-6.

18 Mahida YR, Wu K, Jewell DP. Respiratory burst activity of intestinal macrophages in normal and inflammatory bowel intestinal macrophages in normal
disease. Gut 1989; 30: 1362-70.

19 Mahida YR, Wu K, Jewell DP. Enhanced production of interleukin 1-beta by mononuclear cells isolate from mucosa with active ulcerative colitis and Crohn's disease. Gut 1989; 30: 835-8.

20 Capobianchi MR, Fais S, Mercuri F, Boirivant M, Dianzani F, Pallone F. Interferon-alpha production by human intestinal mononuclear cells. Response to virus in control subjects and in Crohn's disease. Gut 1992; 33: 879-901.

21 Fais S, Pallone F, Squarcia O, Biancone L, Ricci F, Paoluzi $P$, et al. HLA-DR antigens on colonic epithelial cells in inflammatory bowel disease: I. Relation to the state of activation of lamina propria lymphocytes and to the epithelial expression of other surface markers. Clin Exp Immunol 1987; 68: 605-12.

22 Pallone F, Fais S, Capobianchi MR. HLA-D region antigens on isolated human colonic epithelial cells: enhanced 
expression in inflammatory bowel disease and in vitro induction by different stimuli. Clin Exp Immunol 1988; 74:

23 Fais S, Pallone F. Ability of human colonic epithelium to express the 4F2 antigen, CALLA and the transferrin receptor in response to different stimuli. Gastroenterology 1989; 97: 1435-41

24 Belosevich M, Finblood DS, Van Der Meide PH, Slayter MV, Nacy CA. Administration of monoclonal anti-IFNgamma antibodies in vivo abrogates natural resistance of
$\mathrm{C} 3 \mathrm{H} / \mathrm{HeN}$ mice to infection with Leishmania major. f Immunol 1989; 143: 266-74.

25 Rugtveit J, Brandtzaeg P, Halsyensen TS, Fausa O, Scott $\mathrm{H}$. Increased macrophage subset in inflammatory bowel disease: apparent recruitment from peripheral blood disease: apparent recruitment

26 Burgio VL, Fais S, Boirivant M, Perrone A, Pallone F. Increased peripheral monocytes and naive $T$ cells recruitment and activation in Crohn's disease. Gastroenterology (in press). 